Bhani Sharan Kaur, BSW, York University, 2008

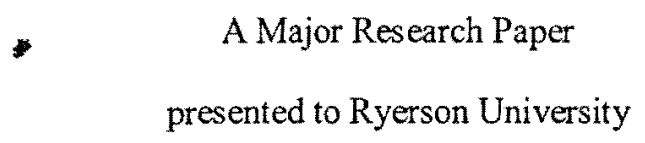

in partial fulfillment of the requirements for the degree of

$$
\text { Master of Planning }
$$

in

Urban Development

Toronto, Ontario, Canada, 2010*

(c) Bhani Sharan Kaur 2010* 
I hereby declare that I am the sole author of this major research paper.

I authorize Ryerson University to lend this paper to other institutions or individuals for the purpose of scholarly research.

Signature

I further authorize Ryerson University to reproduce this paper by photocopying or by other means, in total or in part, at the request of other institutions or individuals for the purpose of scholarly research. 


\section{TABLE OF CONTENTS}

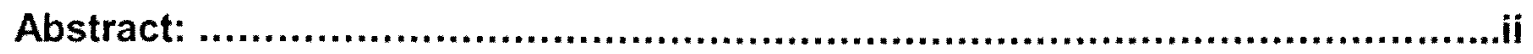

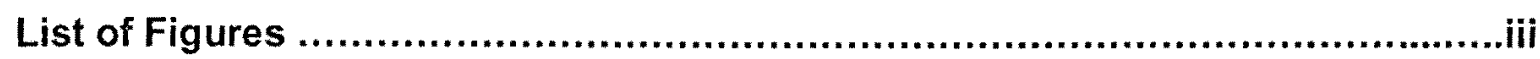

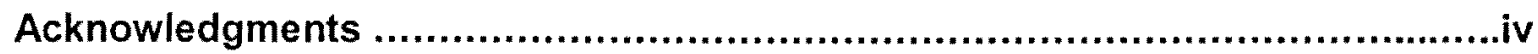

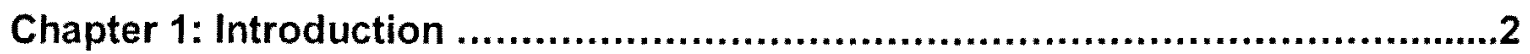

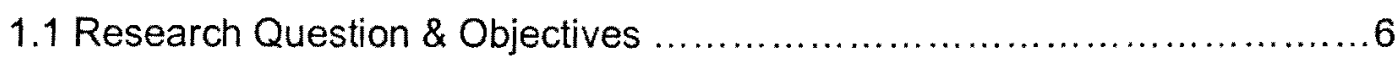

Chapter 2: Literature Review .........................................................

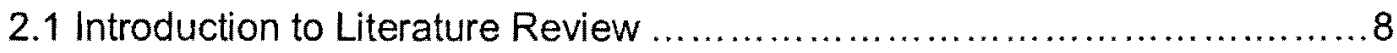

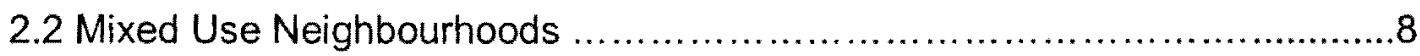

2.3 The Definition of Mixed Use .............................................. 10

2.4 Characteristics of Mixed Use Neighbourhoods ............................ 10

2.5 Various Perspectives about Mixed Use Neighbourhoods ...................11

2.6 Consequences of Mixed Use Neighbourhoods ..........................13

2.7 Conflicts in Mixed Use Neighbourhoods ................................... 14

2.8 Incompatible Uses ........................................................ 16

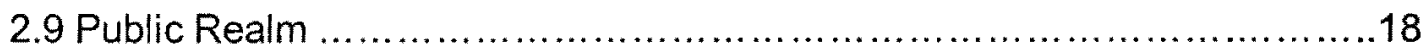

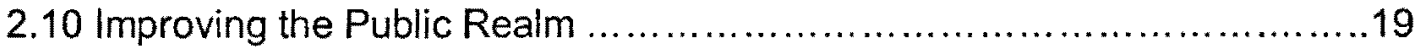

2.11 The relationship between Urban Design and the Public Realm ............21

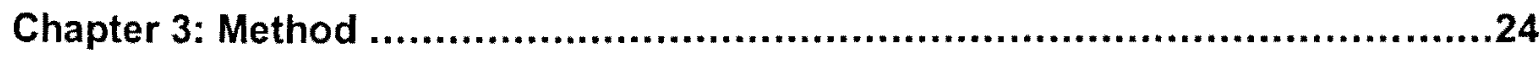

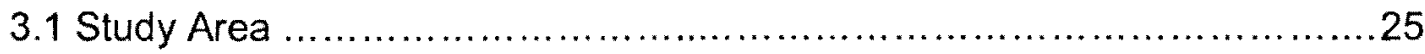

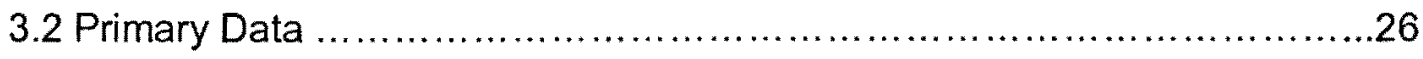

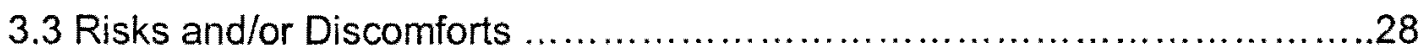


3.4 Secondary Data .28

3.5 Confidentiality .29

Chapter 4: Case Study - King-Spadina 30

4.1 History of the King-Spadina Neighbourhood 30

4.2 The Development of Clubland 33

4.3 Changes in the King-Spadina Neighbourhood .35

4.4 Safety Concerns in the King-Spadina Neighbourhood 36

4.5 The King-Spadina Public Realm 39

4.6 Attempts to facilitate changes in the King-Spadina Neighbourhood 41

Chapter 5: Conclusion 45

5.1 Discussion 45

References 51

Image Sources 


\title{
CONFLICTS IN MIXED USE NEIGHBOURHOODS - CASE STUDY: KING-SPADINA
}

(C) Bhani Sharan Kaur, 2010

\author{
Master of Planning \\ in \\ Urban Development \\ Ryerson University
}

\begin{abstract}
This research paper focuses on the phenomenon of mixed use neighbourhoods, specifically in the case of the King-Spadina neighbourhood located in the City of Toronto. This paper will examine the benefits of mixed use neighbourhoods and the issues that arise when two or more incompatible land uses are located within a given geographical area. The focus of this paper is on the case study area of the King-Spadina neighbourhood which is home to the Canada's largest Entertainment District, an area which previously served as one of Toronto's industrial cores. Since the elimination of traditional land use restrictions in the area, the King-Spadina neighbourhood has seen an influx of redevelopment in both residential and commercial. This paper seeks to address the current conflicts associated with having a concentration of entertainment facilities located within a community with a residential population. Through a rigorous research process, this paper aims to address how enhancing the public realm can create a more enjoyable mixed use neighbourhood.
\end{abstract}

Key words: Mixed Use Neighbourhoods, Incompatible Land Uses, Public Realm, King-Spadina 


\section{LIST OF FIGURES}

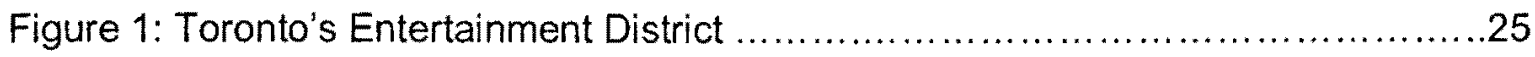

Figure 2: An old industrial building on Adelaide Street ................................40

Figure 3: Makeshift sidewalk on Peter Street .......................................41

Figure 4: Limited sidewalk space on Peter Street .................................41

Figure 5: Toronto Entertainment District Master Plan: Public Realm Framework .......43

Figure 6: Richmond St. and Adelaide St. before and after renderings ................... 44 


\section{ACKNOWLEDGEMENTS}

I would like to extend my sincere gratitude to those who have provided me with much support and encouragement - to my family, friends, and supervisor Dr. Cecilia Zhuang and second reader Dr. Steven Webber. While this process was difficult and demanding your constant support and guidance is greatly appreciated. I would also like to say thank you to Toronto City Planner Jamaica Hewston for her providing her professional insight and serving as an additional reader. 


\section{Chapter 1: Introduction}

In recent years, there has been much discussion about the concept of mixed use neighbourhoods amongst various planners and academics (Lynes \& Murray, 2009). Mixed use neighbourhoods are defined as those which contain a composition of various land uses within a given geographical area (Frank, nd, pg.9). Mixed use has become a phenomenon amongst planners worldwide seeking to create well balanced communities.

There are many benefits associated with mixed use neighbourhoods. For example, mixed use neighbourhoods are often seen as sustainable communities which are intended to allow for growth by increased density, improved urban design in the public realm, pedestrian space, affordable housing, transit accessibility, vibrant local economic sector, innovative design, reduced vehicle related emissions, and an overall vibrant community (Klien, 2008). Taking this into account, mixed use neighbourhoods are also often seen as desirable communities, primarily because they promote accessible neighbourhoods where people can live, work, and shop in addition to having access to a wide range of amenities. Planners today are working towards integrating sustainable planning into urban and suburban communities by creating accessible, integrated mixed use neighbourhoods that rely less on the dependency of cars and more on public transit.

While these multifaceted neighbourhoods are desirable, the issue of incompatible uses and conflicting interests amongst land users does arise (Grant, 2002). For example, in the case of residential versus entertainment, residents may have concerns 
with the nature of the entertainment facilities, such as noise, spill over after hours, violence and safety concerns. As such, if mixed use neighbourhoods are going to continue to be a popularly promoted form of development, planners and municipalities need to take into account the changes that constantly take place in neighbourhoods so that they can foster a space which balances the wants and needs of its various users.

This research paper focuses on the phenomenon of mixed use neighbourhoods, specifically in the case of the King-Spadina Entertainment District located in the City of Toronto. There has been a constant battle between residents and business owners in the neighbourhood in regards to who the space belongs to. Each land user appears to feel a sense of entitlement to the space and is leaving very little room for compromise. The King-Spadina neighbourhood previously served as Toronto's garment district and was one of the City's industrial cores during the nineteenth century (Canadian Mortgage and Housing Corporation, 2004). The area was predominantly zoned under traditional, heavy-industrial uses with little residential space.

After a period of decline during the 1970 s, as the manufacturing industry migrated into suburban regions, the former City of Metropolitan Toronto ventured to seek a way to stimulate reinvestment in the King-Spadina neighbourhood. In doing so, a new set of planning and zoning amendments were allowed to eliminate the traditional land use restrictions that were in place. The change in the planning framework was considered as a radical planning experiment in which all land-use controls and density numbers were abolished and was based on built form. This allowed for the old industrial buildings to be recycled, revitalized and retained for other uses. 
This drastic change in the planning framework sparked an immediate wave in reinvestment and development, creating a mix of residential, business, and institutional uses with a growing and thriving entertainment district (Planning Partnership, et al, 2006). With the large influx of nightclubs followed by the increased residential developments in the area also came conflicts between residents, the nightclub operators and the club goers. The local resident association has claimed that over the past decade, a large number of improperly operated nightclubs in the area continue to conduct business in violation of provincial and municipal laws as demonstrated by the high percentage of patrons present in the King-Spadina neighbourhood who are either intoxicated, under the influence of drugs or incapacitated by both (King-Spadina Residents Association, 2008, pp.2).

While these claims have been made, enforcement is often an issue as various violations fall upon different departments. For example, if a complaint is filed by a resident in regards to a Municipal Licensing and Standards issue the complaint often may go unseen as an enforcement officer has to witness the infringement in order to issue a notice of violation. This is of great concern to the residents in the neighbourhood due to excessive noise from spill over and safety concerns in turn affecting their quality of life (King-Spadina Residents Association, 2008).The local residents have actively vocalized their concerns and are determined to bring nightclubs into compliance with existing laws and regulations - and if necessary remove those who refuse (King-Spadina Residents Association, 2008). This movement has caused there to be much animosity between the nightclub operators and the residents, with each group claiming rights to the area. 
In addition to the above, further issues that exist in this area have been found in terms of the public realm. As a formerly industrial area, a diminutive amount of concentration was given to the public realm. According to the Canadian Mortgage and Housing Corporation, "little attention was paid in the Kings to public spaces or pedestrian amenities in the past... recognizing that improvements to the public realm would be required to make these industrial districts more attractive" (pg.2, 2004). According to the City of Toronto (2009), there is a lack in streetscaping and pedestrian connections in the public realm due to the fact that this area requires significant funds to make improvements. Due to a limited amount of public and pedestrian space in KingSpadina neighbourhood (specifically in areas concentrated with nightclub venues), issues have arisen as the public realm does not have the capacity to hold the some. 60,000 plus of club goers that flock the area nightly (Clubland, 2008).

It is apparent that the issues stated above appear to be intertwined. While there continues to be an increase in developments and a growing population in the KingSpadina neighbourhood, the public realm in the neighbourhood is not equipped to handle the large capacity of individuals residing in the area combined with the patrons who use the space. The purpose of this paper is to the explore the concept of mixed use neighbourhoods, the effect of a limited public realm on mixed use neighbourhoods, and possible solutions that can be implemented in order to address and address issues that arise amongst land users.

Although the topic of mixed use neighbourhoods is fairly admired by many (Jacobs, 1961), there have been very few pragmatic studies undertaken that specifically focus on conflicts between entertainment facilities and residential units in mixed use 
neighbourhoods. The lack of research in this particular area affects our understanding as to why conflicts between incompatible land uses exist and how they can be addressed and managed.

This paper will propose that the public realm plays a key role in the development of well-balanced mixed use neighbourhoods. In addition, the elements of designing a public realm can be used as a tool to help address some of the issues in the KingSpadina neighbourhood. The conflict seen between the residents and the nightclub operators in the King-Spadina neighbourhood serves as the rationale and justification behind the research. Moreover, the results from this research could be further applied to mixed use neighbourhoods across Toronto, facing similar problems as those in the King-Spadina neighbourhood.

\subsection{Research Question \& Objectives}

The purpose of this paper is to the explore the concept of mixed use neighbourhoods, the effect of a limited public realm on mixed use neighbourhoods, and possible solutions that can be implemented in order to address and mitigate issues that arise amongst the various users in the King-Spadina neighbourhood. Furthermore, this research will address the following questions and objectives:

Research Questions:

1. How can issues between incompatible land uses be mitigated in the development of mixed use neighbourhoods?

2. How does improving the public realm play a role in resolving these issues? If so, what would be the most effective solution? 
Research Objectives:

1. To document the evolution of the King-Spadina neighbourhood, specifically focusing on changes in the planning framework.

2. To explore whether or not incompatible uses can co-exist through enhancements in the public realm. .

3. To create possible solutions to mitigate the current issues in the King-Spadina neighbourhood. 


\section{Chapter 2: Literature Review}

\subsection{Introduction to Literature Review}

This chapter offers a review of relevant and representative work accomplished in the field of mixed use neighbourhoods, such as issues relating to conflicting interests, incompatible land uses and enhancing the public realm.

Mixed use neighbourhoods have been in much discussion since they are viewed as a viable solution for sustainable future development. However, there still appears to be major gaps in the general understanding around the dynamics and conflicts between the various land users in areas where there are entertainment facilities alongside residential units. The available research in the field provides the context for explaining the importance of mixed use neighbourhoods and how they allow for a more sustainable future. This literature review aims to address the fundamental principles of mixed use neighbourhoods and the issue of conflicting interests between land users within these neighbourhoods. The primary goal of this literature review is to use the findings and apply them in order to determine what can be done to address conflicting interests of land users specifically in the case of the King-Spadina neighbourhood.

\subsection{Mixed Use Neighbourhoods}

Researchers have documented that at the turn of twentieth century, cities across Europe and North America began segregating land uses. This was done in order to regulate the growth of noxious industries, seen as a result of the Industrial Revolution. The primary reason was to protect residential land uses from noxious uses, such as industrial facilities which were hazardous to the nearby communities. This led to the 
creation of single-use districts (Grant, 2005). Planners at the time sought to enhance safety and preserve land value by putting distance between land uses deemed incompatible primarily through zoning. Moreover, it was based on the belief that the lowdensity lifestyle was a desirable alternative to congested and polluted inner-cities. Land use separation was a means to achieve healthier environments.

The concept around separating land uses came to a full circle by the end of the twentieth century. In the 1980 s, mixed use neighbourhoods become a popular planning principle and strategy in the effort to correct the issues and problems associated with single-use zoning (Grant, 2004). In addition, the healthy cities movement was quite influential in promoting mixed use neighbourhoods as its proponents suggested that "cities should promote health, not detract from it (Hendler, 1989, Witty, 2002). Clean environments, good employment and education, resource conservation, healthy living, and liveable cities are essential to human and environmental health" (Grant, 2005). Near the end of the decade, this movement suggested that mixed use neighbourhoods would be a possible solution to urban problems (Grant, 2005).

The trend of segregating land uses became irrelevant as inner city neighbourhoods suffered a decline while suburban areas grew. This eventually led to people preferring mixed use neighbourhoods since they reduced their travel needs and dependency on cars as a mode of transportation and increased walkability through creation of accessible spaces. (Grant, 2005) This encouraged the growth of vibrancy, variety, and sustainability in these neighbourhoods (Coupland, 1997, Grant, 2005). 


\subsection{The Definition of Mixed Use}

The term mixed use is often referred to, yet not consistently defined in the academic and public world. The majority of academic sources refer to this term as a wide variety of development types, including residential, commercial, public and civic (Frank \& Pivo, nd; Coupland, 1997; Grant, 2005). According to Frank et al, mixed use neighbourhoods are defined by a composition of various land uses within a given geographical area (nd, pg.9). Cervero (1988) further defines mixed use neighbourhoods as those which contain offices, shops, restaurants, banks and other activities intermingled amongst one another.

While several academic sources state that mixed used use implies an integration of various uses in a specific area, there often appears to be confusion in the literature around the scale in which mixed use can be applied (Coupland, 1997). Clements et al, (2007) state that mixed use developments or neighbourhoods are not based on a standardized scale; they can differ in location and can be built in both an urban and suburban setting. There is no conclusive literature that states that there is a specific configuration or definition of a universal mixed use design; rather it depends on the density of the neighbourhood (Clements, et al, 2007, Gardiner, nd).

\subsection{Characteristics of Mixed Use Neighbourhoods}

Several North American studies and guidelines have stated that there are specific characteristics and criteria needed for a community to be deemed mixed use (City of West Salem, 2008; Atlanta Region Commission, nd). In addition to a variety of mixed uses, these characteristics and criteria include: allowing for urban growth by 
increasing density, improved urban design in the public realm including ample pedestrian space, connectivity, and way finding, affordable housing, transit accessibility, sense of place, convenient parking, innovative design, traffic calming measures, pedestrian scale, and sustainability through a reduction in vehicle related emissions. The Atlanta Region Commission (nd) has noted that acknowledging these characteristics brings essence to mixed use neighbourhoods. This is due to the fact that this type of neighbourhood allows people to be closer to the things they need on a daily basis, such as grocery stores, recreational facilities, employment opportunities and institutional centres, which in turn provides more options for both residents and workers.

\subsection{Various Perspectives about Mixed Use Neighbourhoods}

While the concept of mixed use neighbourhoods is often primarily discussed in the context of urban communities, some academics find that the concept attacks suburban living. For example, Peter Gordon, a professor of Planning and Economics at the University of Southern California's School of Urban Planning and Development, has challenged the views of many progressive academics who promote living in urban mixed use neighbourhoods. He claims that cities have moved from urban communities towards suburban living and have placed pressure on car-oriented developments because that is what residents prefer.

However, while advocates of mixed use neighbourhoods state that the people prefer to live in communities where they can work, Gordon believes in the opposite and this is seen in his arguments against mixed use neighbourhoods. He claims that people do not necessarily want to live in the same neighbourhoods where they work and that 
mixed use are not necessarily ideal for all. For example, in a 1998 interview with Reason Magazine Gordon states that:

When you study the economics of location, all the textbook models say a firm wants to locate near the urban core or other advantageous sites, and workers must make their living arrangements so that they are close to their jobs. That may be the way it was once upon a time... They want to go where the labor force wants to go. The workers and their families want to live where the land is cheap and the air is clean and the schools are good and there are high amenities and so forth. There's a lot more spatial flexibility than ever before, and the consequences are pretty benign. People don't have to live near work. They can be near good schools if they want to be without paying the price in longer- duration commutes. If you make travel less expensive, there will be more travel. (Moore \& Henderson, 1998, pp.4)

However, while he raises a valid point, Gordon's arguments appear to be primarily economic, as he discusses the trade off between accessibility and housing prices.

Other critics have claimed that while mixed use neighbourhoods may be a cure for urban degradation, residing in such a neighbourhood is not realistic for all, especially for families as they become too expensive for people living in it and seldom offer single family homes or apartment spaces large enough for families (Gallent et al, 1998). Other critics have further stated that the concept is "a passing fad that provides housing only for higher income professionals" (Tombari, 2005, p.2).

The late Jane Jacobs, who was an American-born Canadian writer and activist, was a huge supporter of mixed use neighbourhoods. She argued in her timely released book, The Death and Life of Great American Cities (1961) that "fine-grain mixing of diverse uses creates vibrant and successful neighbourhoods" (Stiftel \& Watson, 2005, pg.17). Jacobs was a firm believer in cities as forms of ecosystems. She suggested that buildings, streets and neighbourhoods function as unique organisms, which change in 
response to how people interact with them. She explained how "each element of a city sidewalks, parks, neighbourhoods, government, economy - function together synergistically in the same manner as the natural ecosystems" (Project for Public Space, nd, pp. 16). She advocated for the integration of various building types, such as old and new residential and commercial buildings.

Jacob's strong beliefs around mixed use neighbourhoods became quite common by the late 1960s. Fellow activists and planners saw mixed use neighbourhoods as a desirable strategy in urban revitalization opposed to the urban renewal approach based on demolishing downtown neighbourhoods and buildings by replacing them with higher income oriented commercial and residential uses. It was quite apparent that by the late 1980 s, mixed use neighbourhoods became a common discussion in academic literature and at professional conferences (Grant, 2005, \& Calthorpe, et al, 2001).

\subsection{Consequences of Mixed Use Neighbourhoods}

Powell (2004) discusses the risks involved in urban renewal through mixed use neighbourhoods and states that while most local municipalities and agencies are now encouraging mixed use, there are various competing interests. He states that by allowing mixed residential and commercial use in a specific geographical area, it can trigger unintended consequences, such as unreasonable increases in rent and unaffordable housing, which could likely lead to gentrification. This can be caused if the neighbourhood becomes more desirable to an influx of higher income individuals, which indirectly pushes the previous owners out due to unaffordable housing prices in the area 
(Duamy, 2000). Gentrification may not always be a result but is a possibility in highly desirable mixed use communities.

\subsection{Conflicts in Mixed Use Neighbourhoods}

While it is evident that the majority of research and literature available is highly favourable of mixed use neighbourhoods, Lynch (1984) states that "good mixed-use exist just before conflict occurs". Zelinka, Smart \& Kunz (2002) explore mixed use obstacles to optimize urban success stating that in order for there to be true success, there must be a proper balance between the various needs of different land users and that they must be compatible and acceptable to the surrounding context.

Zelinka et al. (2002) further state that while it may be difficult, successful mixed use neighbourhoods occur when the needs and desires of the majority of potential users are met. For example, residents often value their serenity while restaurant and bar owners may value outdoor patios and the ability to provide live entertainment after hours. In addition, they state that there are often urban and physical design challenges that must be addressed in order to prevent further conflicts amongst inhabitants (Zelinka et al, 2002). These include parking, noise, loading areas, connectivity, waste, transition areas/screening and density.

According to the California Downtown Association (nd), the following public and private design challenges must be addressed to overcome conflicts in mixed use neighbourhoods:

Parking: Residents of mixed use projects are concerned about the security of their vehicles as well as having available parking spaces for themselves and their guests. To accomplish this, residential parking spaces should be 
separated from spaces dedicated to commercial uses, and secured with gates or provided with separate entries. Among the various commercial uses within a mixed use project, shared parking scenarios may be appropriate, reducing the number of parking spaces a developer must provide. Shared parking scenarios take into account the different peak parking needs of different uses at different times of the day.

Noise: The expectations of residents for a quiet home must be balanced with the realities of commercial uses. Structural design should incorporate appropriate materials to buffer sounds between residential and nonresidential uses. In instances where physical design cannot fully address noise problems the regulation of commercial operational hours can be used, and residents can be asked to sign a waiver or disclosure document before moving in.

Loading Areas: Commercial users require adequate loading and docking areas, which residents may associate with noise, dirt and unpleasant aesthetics. Loading areas in mixed use projects must be appropriately screened from residential uses by incorporation of well-designed walls or landscaping.

Connectivity: One of the most cited benefits of mixed use developments is their ability to increase pedestrian, bicycle and transit connectivity. But locating residential, commercial and office uses together is not enough to ensure that the project is accessible to alternative transportation users. Attention must be paid to pedestrian and bicycle connections within the project, and between the project and surrounding uses.

Waste/Refuse: Commercial uses, especially restaurant uses, generate a substantially greater amount of waste than residential uses. The project must provide all users with adequate waste/refuse facilities as well as buffer residential from the unpleasant views and odours of commercial dumpster areas.

Transition Areas and Screening: Landscaping, screening and buildings setbacks should all be used to separate uses when possible.

Density: Mixed use projects are often associated with high density development, however, the density and intensity of a project should be contingent on the surrounding neighbourhood and character to appease the existing community and provide continuity within a neighbourhood. (pg.2, nd)

While the aforementioned challenges mainly cover the issue of design primarily on private property or through public private partnerships, it is important to address what types of issues that have been discussed. 


\subsection{Incompatible Uses}

Grant (2005) points out that planning today generally focuses on creating an appropriate mixture and balance of residential, retail, business, institutional, industrial, and recreational land uses and activities. According to Freedman (1999), attention must be paid when communities and services are changing to ensure that conflicts do not occur amongst users and groups. Conflicting interests often occur when there are competing views on how a space should be used. For example, increasing population in a mixed use neighbourhood could create demands for the use of the land, causing a negative impact on land uses in the near vicinity (Wai, et al, 2003).

Various academic and professional sources use the term nuisance when discussing conflicting interests or incompatible land uses (Robert, et al, 1985). A nuisance often occurs between two or more neighbouring landowners or land uses (Kempsey Shire Council, nd). According to Grant (2002), nuisances are feared when mixing various land uses in a development or neighbourhood. She further asserts that it is often found that people do not want certain types of land uses near them, often presenting nimbyism, the 'not in my back yard' phenomenon as their argument and defence (2002).

It is apparent that it is often the residents of established communities that may resent mixing uses, especially those that are seen as 'incompatible' or those likely to increase urban densities (Grant, 2002, Clark-Madison, 1999, McMahon, 1999, Pendall, 1999). By definition, incompatible refers to opposing characters, unable to exist together in harmony (Merriam-Webster's Dictionary, 2010). In planning terms, this refers to two 
or more uses in close proximity unable to co-exist in peace. (Grant, 2005). Grant (2005) draws upon the example of a 1990 Halifax case in which residents of a newly built apartment building in the downtown core fought the renewal of local bar's liquor licenses, claiming that the establishments (which predated their tenure in the neighbourhood) were a nuisance and ruined their residential enjoyment. She points to a similar case in which the tenants of a thriving nightclub refused to renew their lease after the new tenants in the neighbourhood filed various noise complaints.

Grant (2002) claims that while there is no specific formula for which type of use would be considered compatible to mix into residential or commercial area, it is highly unlikely that land uses, such as prisons and heavy industries, will be integrated into the urban fabric. Schmandt (1999) discusses that while there are certain uses that may be deemed incompatible in various neighbourhoods, municipalities are faced with the choice of empty lots and excessive parking over new offices and/or entertainment facilities. Schmandt (1999) implies that municipalities may be confronted with the decision of making a trade off in terms of how space should be used and that it may be more advantageous for them to allow for certain uses to occupy a space which is otherwise underutilized.

In order to address the issue of incompatible land uses, the concept of buffering is often discussed. By definition, a buffer is a physical land separation between land uses (Kempsey Shire, nd). There are two types of land buffers: adjoining buffer and geographic buffer. An adjoining buffer is a buffer that immediately adjoins a land use (Land Buffer Task Force, 2007). These buffers can take the form of a wall, street, or perhaps some vegetation (Land Buffer Task Force, 2007). The second type of buffer is 
a geographic buffer, which is a buffer that features wide natural or planted areas or large permanent geographic barriers that are used to demarcate a formal or informal urban growth line (Land Buffer Task Force, 2007, p.3).

Within mixed use neighbourhoods across North America, buffer distances have been created between incompatible land uses in reducing and avoiding the threat of land use conflicts. There is no set universal formula determining what the minimum distance should be but rather it is determined by the municipality which employs the concept. A buffer is determined based on the geographical neighbourhood and is put in place to prevent certain uses directly adjacent another use (Land Buffer Task Force, 2007, p.3). For example, a residential buffer could be put in place preventing commercial use within a certain amount of square feet of the residential building (Muswellbrook Shire Council Development Control Plan, nd). According to various municipal documents, land use buffers are seen to be successful in decreasing the potential for conflict at various levels although they do not guarantee that issues will be totally removed (Muswellbrook, nd; The Hemson Toronto Land Use Report, 1991)

\subsection{Public Realm}

In addition to addressing incompatible land uses, various academics have claimed that a successful mixed use neighbourhood requires attention to detail in terms of the public realm (Jacobs, 1961). Some define the public realm as the space between private buildings, including boulevards, pavements, streets, squares, parks, etc. (Lofland, 1993). Some may even take it far enough to state that in addition to sidewalks and parks, the public realm includes subways, libraries, museums and art galleries 
(Hume, 2010). For example, Lofland (1989) asserts that the public realm is defined as non-private sectors of urban areas those in which individuals in co-presence are often unknown or only categorically known.

However, McLaughlin (2001) states that "the public realm is the cohesive fabric of an authentic neighbourhood...it is this dominant amenity people find attractive and desirable" (pg.1). Historian and philosopher Lewis Mumford points out that in the past, the public realm has served as "a sacred spot, to which scattered groups returned periodically for ceremonials and rituals, the ancient city was first of all a permanent meeting place (1951,pg.95). This implies that public spaces have been historically used for places of social events either cultural or political. Bacon (1974) further reinforces Mumford's position by asserting that public spaces are those physical areas in communities which societies value and partake in social interaction. Not only does the public realm serve as a space for social interaction or encounters, it creates character for communities.

\subsection{Improving the Public Realm}

In an earlier piece of work, Lyndon (1994) explains that while the public realm is important, various stakeholders and governments must pay focus to these spaces. He further states that these changes can often determine how locals interact with one another (Lyndon, 1994).

A fractured public realm is said to become a symbol of neglect which often is followed by additional neglect (Lyndon, 1995). According to Lyndon, "like many of the complex things we need in our life, public spaces become fractured" $(1995, \mathrm{pg} .1)$. 
Lyndon (1995) believes that it is vital for much attention to be paid to these shared spaces and that the public realm needs constant care, maintenance, repair and policing. He asserts that the changes do not need to be grandeur, but rather could be as simple as paving, sidewalks, trees, tree grating, signage, and lighting.

Loukaitou-Sideris (2009) proposes that urban design is a tool to enhance the public realm. For example, in order to illustrate this point, she draws upon the importance of sidewalks in the public realm. She points out that sidewalks fall under this realm and are often forgotten and understated (2009). She asserts that sidewalks play a contemporary role in urban life and that they are needed in any community. Jacobs (1961) further confirms this by stating that sidewalks are main public places in a city and are vital organs. She advocated for better sidewalks throughout Toronto and argued that "sidewalks were active sites of socialization and pleasure, and this social interaction kept neighbourhoods safe and controlled" (Loukaitou-Sideris, 2009, pg 2).

A study conducted by the Urban Design Compendium (UDC) titled $A$ Thriving Public Realm (2007) states that in order to achieve a thriving public realm, which encourages social interaction and integration, attention needs to be given to the actual structure of the space and the elements it contains. The study states that within a public. realm, attention needs to be given to the following elements: social space, distinctive places, street furniture, signage, lightening (UDC, 2007). These elements are seen through a design perceptive. Social space areas of the public realm, such as squares and sidewalks, are places in which people often travel through routinely and need to be designed with versatility in mind to enable a range of different uses and activities (UDC, 
2007). Distinctive Places are in reference to attractiveness, durability, maintenance, and sustainability to enable longevity (UDC, 2007).

Street furniture is seen as a key component in a good public realm as not only does it provide objects, such as waste receptacles, benches, and bike stands, but also incorporates and encourages public art which promotes character and identity for the area (UDC, 2007). Signage not only allows for places to be identifiable, but proper signage on both private and public property can create character if done in innovatively (UDC, 2007). Lastly, Lighting is not only an aesthetic feature in a neighbourhood, but rather can increase the perceived safety in an environment and can be done through bollards, street lights, faced lights, and store front lights (UDC, 2007). The above elements concentrate on fundamentals of the public realm by creating character for a space which in turn can be a formula for a good public realm (UDC, 2007).

\subsection{The relationship between Urban Design and the Public Realm}

The fundamentals of the public realm and urban design are intertwined. Vancouver's Public Space Network states that "not only is good design an important feature of effective, people-friendly, public spaces, but the presence of public amenities - parks, squares, laneways, public art and more - plays an integral role in shaping the city" (2009, pp.1). Enhancing the public realm places a key role in mixed use neighbourhoods as it is used as a visual motif to achieve high quality of life that promotes liveability (City of Rockville, nd). In practical terms, McGill University's School of Architecture goes on to explain the concept by stating that "urban design provides a set of descriptive and analytical tools for working with the tangibles of landscape, built 
form, land use, and hard infrastructure. Its concepts and methods also enable us to examine and make sense of how people use space. Critical, then, is life between buildings" (2009, pp. 4)

Urban design incorporates the various concepts of a city including building design, public space, environmental space, transportation, public art, and several other amenities that contribute to the overall dimension and character of an area. According to the Houston Galveston Area Council Urban Design best practices toolkit (nd), urban design can be applied through a dimensional approach, and through the built environment such as buildings, streets, sidewalks, parks and plazas. These can be addressed by enhancing the aesthetics such as streetscaping, landscaping, building setbacks, and architectural design.

The Council further states that at a local level, urban design tools, such as streetscaping, play a vital role as it gives the space a "look and feel" in turn improving the area's liveability and creating a good public realm (Houston Galveston Area Council, nd). Urban design aims to create a viable and thriving public realm, one which is focused around public space. It is evident that creating more attractive and viable public realm can be advantageous through various elements such as streetscaping, lighting, and signage. However, there is little literature that states how these elements can specifically resolve issues of competing interests and incompatible land uses in areas comprised of entertainment facilities and residential units.

Nonetheless, the fundamentals of the public realm and mixed use neighbourhoods are very similar. As the literature above has stated, mixed use 
neighbourhoods focus on walkability and various uses in a specific geographical area, whereas, the public realm is the space in which people travel through. For example, those who live in mixed use neighbourhoods use the public realm to travel from point a to $b$. Within these mixed use neighbourhoods, the public realm a shared space in which the various inhabitants and patrons co-exist. Creating a public realm in which the needs of all its users are met is an ambitious and desirable goal for many communities. While it may be impossible to create a space which meets the needs of all the users, the purpose behind this goal is to create a viable and diverse community that allows for mixed uses and the co-existence of its users. 


\section{Chapter 3: Method}

As seen in Chapter 1, the existing literature provides a significant amount of data in regards to mixed use neighbourhoods and the public realm. The literature proves that there is a great connection between the two concepts and that in order to have a successful mixed use neighbourhood, the public realm needs to be equipped to handle all or the majority of its potential users. However, there is limited insight and analysis into conflicting interests in the mixed use neighbourhoods similar to the King-Spadina neighbourhood. This paper aims to minimize the research gaps through secondary research analysis, informal interviews and a nonreactive unobtrusive study.

Three primary research methods were used to provide qualitative data in support of the purpose and objective of this research: literature review, semi-structured interviews and participant observation. While the research questions proposed in Chapter 1 are specific to this project, the nature of this study required that a wide range of literature be explored. The research has been drawn from literature in planning, landscape architecture, sociology, and environmental psychology. With these various fields in mind, focus was placed upon mixed use neighbourhoods and the planning and design of the public realm.

In order to gain a better understanding of these issues and this area, semistructured interviews were conducted with Toronto City Councillor Adam Vaughan and Toronto Entertainment District Business Improvement Area Executive Director, Janice

Soloman. These interviews were facilitated based on professional practise. Collectively, the literature review, participant observation and semi-structured interviews were 
effective in providing key information needed to scope the research in addition to providing information that could support the case study of the neighbourhood of KingSpadina. Various research methods were considered such as interviews with residents and business owners. However due to the sensitivity of the topic and time constraints, it appeared that the best method would be to speak to the representatives of each group.

\subsection{Study Area}

This study was conducted by employing the qualitative method that utilized general observations and open-ended interviews with public figures. The case study is focussed on the King-Spadina neighbourhood, also referred to as the Toronto Entertainment District (as seen in Figure 1), located in the core of downtown Toronto. The area boundaries are west to Bathurst Street, north to Queen Street, east to Simcoe Street and south to Front Street. Due to the nature of this study, the sample population drawn from was the inhabitants and patrons of the King-Spadina neighbourhood.

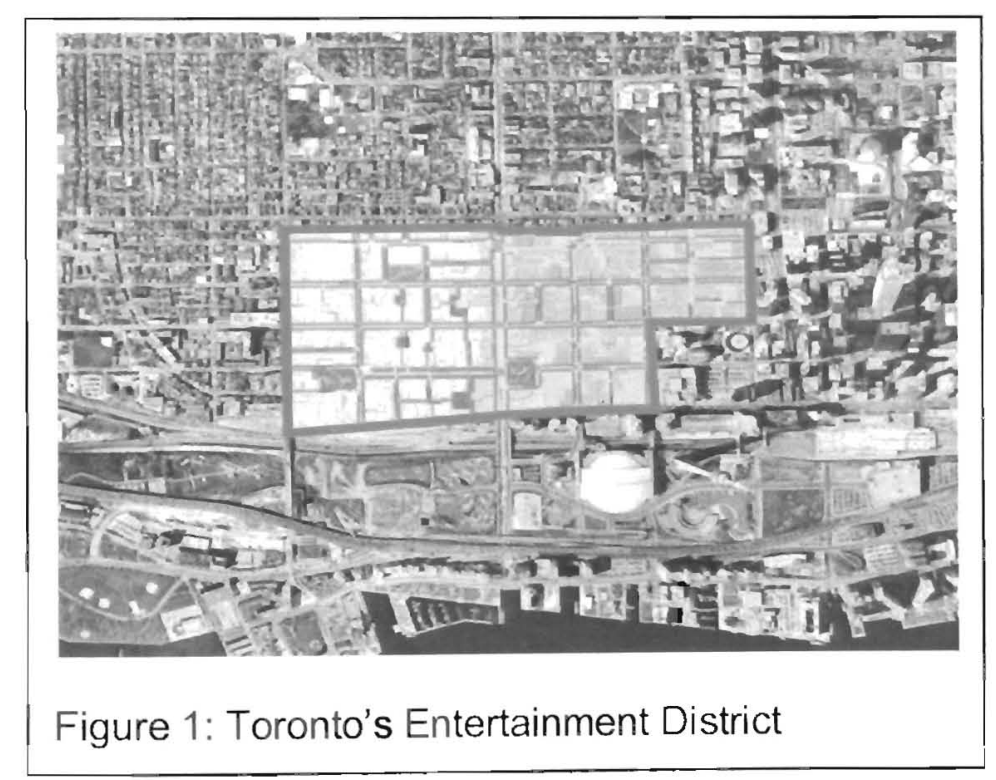




\subsection{Primary Data}

According to the Toronto Entertainment District Master Plan (2008), there is an underlying conflict in the King-Spadina area between the local residents and the entertainment business operators. In order to get a complete understanding, a study was conducted focusing on the residents, the business owners and the patrons of the area. Two informal interviews were conducted for the purposes of this research. These interviews were conducted in order to collect the data and information necessary to validate the secondary research used in this paper. Interviews were conducted with City Councillor Adam Vaughan and the Executive Director of the Toronto Entertainment Business Improvement Area, Janice Soloman.

These interviews were conducted through the use of semi-structured questions with both Janice Soloman and Toronto City Councillor Adam Vaughan on separate occasions to validate the information that has been stated in the literature, through the media and brought forward by local residents and business owners of the King-Spadina neighbourhood. The questions asked were strictly for the purpose of gaining factual information. Both Janice Soloman and City Councillor Adam Vaughan act as representatives of the area hence their feedback was vital as the information they provided was based on what business operators and residents have stated.

In addition, an observational study was conducted over a number of days and various site visits. The sites that were studied were specifically Richmond Street, Peter Street, Adelaide Street and King Street. These streets were chosen as they have high concentrations of nightclubs in a specific area adjacent to several residential units. During each visit, the interaction between the various land users and patrons was 
observed and photographed. Data was written down and inferences were made.

Photographs were taken to capture and depict the current state of the neighbourhood and to illustrate the current state of the public realm. Site visits were conducted during the following times:

- Friday January $15^{\text {th }}, 2010$ from $1: 00 \mathrm{pm}$ to $5: 00 \mathrm{pm}$

- Friday January $15^{\text {th }}, 2010$ from $8: 00 \mathrm{pm}$ to $12: 00 \mathrm{am}$

- Saturday January $16^{\text {th }}, 2010$ from 7:00 am to 9:00 am

- Saturday January $30^{\text {th }}, 2010$ from $10: 00 \mathrm{pm}$ to $2: 30 \mathrm{am}$

- Monday February $1^{\text {st }}, 2010$ from 12:00 pm to $1: 00 \mathrm{pm}$

- Saturday February $6^{\text {th }}, 2010$ from 9:00 pm to 1:00 am

- Sunday February $7^{\text {th }}, 2010$ from 7:00 pm to $9: 00 \mathrm{pm}$

The purpose of conducting the observational studies at various times was to contrast how the space is used during different times. For example, it is evident that there is a difference in how the space is used on a Friday night when almost 60,000 people are present to attend the various night clubs in the area compared to a Monday during noon where the space is empty (Clubland, 2008). Observational studies were conducted during the above times with no direct human interaction in the area. These observations were made at different times during the day and on different days allowing for a deeper understanding of the overall neighbourhood dynamics.

Furthermore, an investigative ethnography was used for the purpose of participant observation and interviews. According to Neuman (2006), ethnography means "describing a culture and understanding another way of life from the native point 
of view" (p.381). To adopt the native point of view, interactions among people were observed within the King-Spadina area. By blending in with public surroundings, human interactions were observed perceptively and assessed through the prism of civil inattention.

\subsection{Risks and/or Discomforts}

Special care was taken to ensure that individual privacy was not invaded and no unauthorized photographs were taken. Due to safety concerns, photographs were not taken at night or during times when there were large groups of individuals in the area. Rather, detailed notes were taken and inferences were made based on observations. Photographs taken were solely for academic purposes and a conscious effort was made to make sure no individual is identifiable in the images used.

\subsection{Secondary Data}

In addition to the interviews conducted, a significant amount of data was collected through secondary research and primary data (site observations). One of the major sources used for this research was a documentary that was produced to showcase the conflicts between residents and nightclub operators in the King-Spadina neighbourhood. The documentary titled Clubland was produced in 2008 by Eric Geringas and consists of interviews with the various stakeholders and residents in the King-Spadina neighbourhood. Several news articles and official documents were reviewed to map out the history of the King-Spadina area and document the underlying factors to determine how and when the incompatible land use issues began and further evolved. Lastly, another document that was relied on was the Toronto Entertainment 
District Master Plan (2008), which is a multi-faceted long term plan to enhance the Entertainment District.

\subsection{Confidentiality}

One of the concerns stated by the individuals interviewed was that the information or opinions they state can be used for defamation purposes. The interviews conducted were done in strict confidence and information stated off the record was not used in this research paper. For the purposes of this paper, only factual information has been used. 


\section{Chapter 4: Case Study - King-Spadina}

The Toronto Entertainment District is a multifaceted neighbourhood located within the King-Spadina area. This neighbourhood is home to some of Canada's most notable landmarks including the CN Tower, Rogers Centre, Air Canada Centre, CBC, CTV, Metro Toronto Convention Centre, Roy Thomson Hall, the Princess of Wales Theatre and the Royal Alexandra Theatre (Toronto Entertainment District Business Improvement Area Master Plan, 2009). The area holds great significance and planning history and is notably one of most spoken of mixed use neighbourhoods in the nation for both its intensification and conflicts (Klien, 2008).

\subsection{History of the King-Spadina Neighbourhood}

The King-Spadina neighbourhood previously served as one of Toronto's industrial and manufacturing cores during the nineteenth century (Canadian Mortgage and Housing Corporation, 2004). The area was known as the garment district and was predominantly zoned under traditional, heavy-industrial uses. There were large warehouses and very little residential space, preventing almost any other type of modern development activity to take place. The area entered a period of decline during the 1970 s as the manufacturing industry migrated into suburban regions (Canadian Mortgage and Housing Corporation, 2004). Due to this decline, the former City of Metropolitan Toronto ventured to seek a way to stimulate reinvestment and intensification in the King-Spadina neighbourhood.

The neighbourhood was one of the first areas in Toronto to be freed from planning controls when former Mayor Barbara Hall and Toronto City Council approved a 
new set of planning and zoning amendments. These amendments allowed them to eliminate the traditional land use restrictions in place in both the King-Spadina and KingParliament neighbourhood to encourage and promote reinvestments, housing opportunities and creative spaces for new businesses (Canadian Mortgage and Housing Corporation, 2004).

Former Metropolitan Toronto Planners Ken Greenberg and Paul Bedford and others with the guidance of Jane Jacobs managed to remove all but two zoning rules: (1) new buildings could not be set back from the street and (2) the height of new buildings had to be no greater than existing buildings (City Comfort, 2004). Built formbased regulations dictated how the buildings could be used as long as they followed these two requirements. At the time, this new approach to planning took away power from planners and politicians and put it in the hands of the property owners allowing for innovative developments to spread throughout the area (City Comfort, 2004).

The approach was based on built form, an approach which promotes "designbased strategies based on "traditional" urban forms to help arrest suburban sprawl and inner-city decline and to build and rebuild neighbourhood, towns, and cities" (Bohl, 2002, p.2). This new planning framework allowed the city to step away from the traditional approach of "segregating land uses and regulating the size of development with density and parking replaced with a more flexible planning approach" (City of Toronto, 2002, pg 2). In an evaluation of the effectiveness of the new planning framework in the King-Spadina neighbourhood, the City of Toronto's created a report titled Regeneration in the Kings (2002) which included the following approaches: 
- as-of-right development permission within general height limits;

- maximum flexibility in land use policies to permit new buildings and conversions of existing buildings to almost any commercial;

- light industrial or residential use;

- the removal of density numbers from the Part II Official Plans and Zoring Bylaws;

- new built form regulations focusing on building height, massing and light, view and privacy standards; and

- the relaxation of a number of general bylaw standards regarding parking and loading, with exemptions being given to existing and heritage buildings. $(2002$, p. 3$)$

These new zoning amendments were approved by Toronto City Council along with the new King-Spadina Secondary plan. This approach was intended to deregulate land use and suspend the industrial policies in place to allow a new regulatory system based on built form. This meant that any new developments had to reinforce the look and feel of the neighbourhood (City of Toronto, 2002).

Prior to these changes taking place, a consultation process was held leading up to the zoning amendments and adoption of the King-Spadina Secondary Plan. At the time of the change, there was very little residential opposition to the policy change as the number of people residing in the area was relatively low. The general consensus among the land owners in the area was an overall support for the policy changes, since it removed many of the barriers to subsequent development (Canadian Mortgage and Housing Corporation, 2004).

By implementing these changes, the city hoped to attract a variety of mixed land uses including light industrial, commercial, entertainment, retail, residential and 
live/work, which would preserve the physical and heritage characteristics of the area and encourage a connection between residential and employment uses (City of Toronto, 2006). In addition, an important objective of this shift was to create a positive environment for regeneration and economic growth, retaining the special physical and heritage character of the built environment and assure a good quality working and living environment (Canadian Mortgage and Housing Corporation, 2004).

\subsection{The Development of Clubland}

There is a common misconception as to the factors that prompted the influx of entertainment establishments in what is today referred to as the Entertainment District or also known as Clubland. It was not necessarily the new planning framework that prompted these clubs to move into the space, but quite the opposite. The new planning approach was put in place to promote other developments to use the space with the goal of creating a mixed use neighbourhood. According to the documentary Clubland (2008), the first nightclub in the area opened in 1988 called Stillife was opened by Entertainment pioneer, Charles Khabouth, after the migration of the manufacturing businesses from the area. The old industrial and manufacturing buildings were a perfect fit for entertainment purposes due to the open interior and large capacity. The early success of the original clubs in the area prompted a mass explosion of new clubs in the 1990s with the city's approval. According to the documentary Clubland (2008):

By 2000 over a hundred nightclubs had opened and tens of thousands of young people flocked from all over. The rapid growth brought others too. Many land developers saw an opportunity to create a neighbourhood for these city fun seekers. A condo boom started and many moved to the area buying up the expensive tiny dwellings. As more people came so too did problems. 
Overcrowding, violence, drugs and accompanying headlines became the norm. With thousands of new residents living in the district, the wild and crazy late nights were starting to cause sleepless nights (Clubland, 2008).

Due to the large influx of the development of condominiums in the area, there was a strong residential voice present. There was the formation of the King Spadina Residents Association, a strongly voiced group of individuals on a mission to ensure that club owners obey municipal and provincial regulations. The group claims that various nightclubs continue to violate municipal and provincial regulations, including Municipal Licensing and Standards violations. The group has gone as far as creating templates against any liquor license applications in the area in an attempt to prevent any new entertainment establishment from opening.

Over the past several years with the increase of residential developments in the Entertainment District, the King Spadina Residence Association has been extremely vocal about their concerns. The majority of tineir concerns to this day stem from noise and disturbance that spills over after hours when individuals are leaving clubs, restaurants and lounges in the King-Spadina neighbourhood. City Councillor Adam Vaughan, who is the local Councillor for Ward 20, Trinity Spadina states that "residents are not opposed to the clubs; it is the extreme concentration of them that is the issue" (personal communication, 2010). The area appears to be a victim of its own success, an ever growing club district, one which prompted many residents to move into the area has suddenly become an issue.

The King-Spadina area has seen reinvestment in both businesses and housing opportunities allowing there to be continuous growth with an addition of well over 4000 
new dwellings units to the downtown housing stock (City of Toronto, 2002). According to the City of Toronto, the general demographic of the area is younger adults, without children, who for the most part work in the downtown core (2002). Approximately $40 \%$ of the individuals living in this area are those between the ages of 20-34 (City of Toronto Census Data, 2006). While it is quite apparent that this type of mixed use neighbourhood has many benefits including its location and close proximity to various types of land uses, the issue in this case revolves around the fact that the concentration of nightclubs in the area are clashing with the residential community. The following sections will further examine these issues.

\subsection{Changes in the King-Spadina Neighbourhood}

Since the implementation of the new planning framework in addition to the growth of nightclubs and condominiums, there has been a marked rejuvenation in the economic development of the King-Spadina neighbourhood. This has led to the formation of a highly desirable residential area creating a mixed use neighbourhood. The area is often referred to as the epitome of urban regeneration. This new less restrictive planning approach has been largely credited for the increase of developments in the King-Spadina area. Since the change in the planning framework as of 2002 , there has had more than $\$ 394$ million dollars worth of redevelopment with an increasing number of business occupancies and full-time employment (City of Toronto, 2006).

While the new planning framework promoted investment in both residential and additional entertainment uses in the area, complaints have risen as more and more 
condominium dwellers move into the area. To the naked eye in daylight, the area consists of several large industrial style buildings with flashy signs and big black double doors on plain streets. It is not until after 10:00 pm that thousands of people pour into the neighbourhood from across the Greater Toronto Area. Line ups surpass sidewalks and intoxication is prevalent among many club goers.

After the majority of clubs close at 2 am, options become limited. Many individuals flee back home while others stick around to roam the streets, resulting in alcohol-fuelled violence, destruction to property and what the area's City Councillor Adam Vaughan calls "hooliganism" taking over (Mudhar, 2007, personal communication, 2010. Clubland, 2008). The remaining few who are left lurking the area tend to spill over near the residential buildings, screaming, urinating or plain out being belligerent and disrespectful of their surroundings. The cause of this contention appears to be the mere concentration of clubs in a 1.5 square kilometres of space (Clubland, 2008). To address this issue, City Councillor Adam Vaughan has aggressively monitored the area, even suggesting venues get permits for line-ups (personal communication, 2010). The idea of these venues obtaining sidewalk permits seems like a sensible and fair requirement similar to what restaurants do when they want to set up patios directly outside their restaurants.

\subsection{Safety Concerns in the King-Spadina Neighbourhood}

According to Staff Sergeant Shaun Narine of 52 Division, who routinely patrols the Entertainment District, as of 2009 the number of nightclubs operating in the area has decreased down to 30 with a few more in the works of moving in (Siddiqi, 2009). 
This is a significant drop considering that there were over 100 nightclubs in the area at the turn of the millennium (Clubland, 2008).

With such a large concentration of nightclubs in the area comes the issue of safety and disturbance. Despite the fact that there are over 140 police officers patrolling the Entertainment District every weekend, there have been 2600 Liquor Licence Act offences, 63 police injuries and 400 arrests over a 9 month period in 2008 (Raising the Bar forum, 2008). The residents' concerns should be nothing less than extreme considering the fact that the majority of clubs in the district are considered level 1 (level 1 being the highest of a 4-level grading system) with respect to Risk Based Licensing (Raising the Bar forum, 2008).

City Councillor Adam Vaughan states that "we suck police resources from across the city into one little neighbourhood, to police a bunch of basically hooligans" (Gray, 2007). To further validate this argument, the Toronto Police reported at the 2008 Raising the Bar forum that between January and October 2008, 22,000 police hours were spent policing the Entertainment District, $\$ 900,000$ were spent in pay, $\$ 150,000$ in overtime and approximately $\$ 2,000,000$ to police the district, all of which could be better distributed throughout the city if this issue was properly mitigated.

It is quite clear the demographic and sheer numbers of people who use the space are the key instigators in this problem. The district is often crawling with thousands of people after $8 \mathrm{pm}$ on a weekend, with individuals from the Greater Toronto Area and beyond. Adam Vassos, a lawyer who represents several of the local nightclubs states that "the industry is being treated unfairly and its problems are 
exaggerated" (Gray, 2007). The issues are not exaggerated as my observational study proved that there is merely no space to walk on public property without feeling like you may be shoved into moving traffic, City Councillor Adam Vaughan further validates this point by stating that residents have brought this to his attention (personal communication, 2010).

While this explosion of development in the area could have unlikely been expected back in 1996, the Urban Design Guidelines, which were created in response to the new mixed use area, did mention the possible conflicts and "warned that it would be necessary to monitor the relationship between residents and those attracted to entertainment facilities"(Mudhar, 2007, p.5). To address these specific issues, the City of Toronto retained the Planning Partnership Firm in 2005 to do a complete review of the King-Spadina Secondary Plan (City of Toronto, 2006). The Planning Partnership report states that "nightclubs have been identified as a specific land use activity that is clearly creating undue, adverse impacts on the community. These undue adverse impacts are a result of the operation of the individual nightclubs, as well as an array of spin-off effects that are a direct consequence of the concentration of the nightclub activities in King-Spadina. There are three basic conflict categories that must be comprehensively addressed to manage the problems, including:

- Noise - Excessively loud music from indoor and particularly outdoor venues. Ambient crowd noise resulting from sheer numbers of patrons milling about in the area at closing time;

- Safety - Control of the outdoor crowds at closing time. Ongoing reports of violence and other illegal activities which threaten the safety of residents, tourists, and clubbers; and,

- Cleanliness - Excessive street garbage from club advertising, as well as from crowds walking the streets and standing in line-ups. The area is also plagued with graffiti and vandalism, although arguably typical of any downtown neighbourhood. $(2005, \mathrm{pg} 3)$ 
While the above issues are a result of such a large concentration of clubs located in a dense neighbourhood, the question to be explored is whether or not enhancing the public realm can provide a solution to some of the concerns to the problem associated with the high concentration of individuals in the area. There are several nodes and corners in the King-Spadina neighbourhood which lack the fundamentals of a good public realm. In addition, the space fosters a very industrial abandoned appearance with large stock buildings lacking any physical character. There is no consistency in the layout and nor is there a sense of community since there is a limited public realm in the neighbourhood. As Lyndon (1995) points out, good models of mixed use neighbourhoods often showcase connectivity and open spaces in the public realm. This is lacking in the King-Spadina neighbourhood. While the space has evolved from its industrial past, the public realm still appears to be stuck in transition.

\subsection{The King-Spadina Public Realm}

When planning any space, whether it be commercial, residential, industrial, recreational or even civic in nature, a considerable amount of attention needs to be placed around the public realm. A community's physical form is most likely the most essential and lasting characteristic in the space. Mixed use neighbourhoods, which are home to various users, require attention to detail to ensure that the space is both interconnected and readily accessible accommodating to all and most its' users.

While the King-Spadina neighbourhood might be a model neighbourhood to many in terms of a highly developed mixed use neighbourhood, several nodes within the area 
lack the general fundamental of a good public realm. Through my observational study and as shown in the Toronto Entertainment District Master Plan (2008), the streets appear to lack connectivity, the sidewalks are bare and poorly lit and there is little sense of a public realm. The different land uses appear to clash not only visually but functionally as well. What is even more troubling is the lack of public space between the various uses.

For a neighbourhood, which is home to some of the most valuable properties in the country, very little nas been done in areas concentrated with nightclubs to enhance the public realm, primarily due to the fact that focus has been placed in areas such as Victoria Memorial Square, Clarence Square, Wellington Street, Spadina and Bathurst Street, King Street, Fortland Street, Front Street and Draper Street (Tinglin, 2009). The majority of the above areas do not have high concentrations of nightclubs with the exception of King Street.

Mixed use neighbourhoods require a high quality of public realm that are weicoming and safe for pedestrians and promote accessibility. Through this observational study, it was quite apparent that many streets within

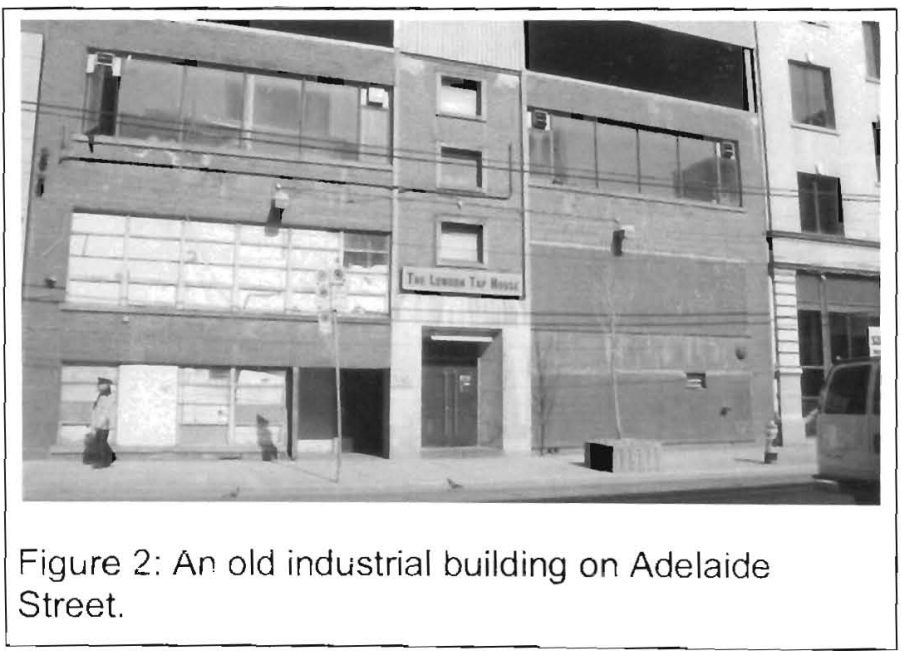
the King-Spadina neighbourhood were not adequately fit for pedestrians due to limited public space, such as sidewalks and squares. Very little is enjoyable about the street 
life on a regular night in the neighbourhood especially on the streets of Richmond and

Adelaide due to the limited

amount of space for people to

travel through safely.

\subsection{Attempts to facilitate}

\section{changes in the King-Spadina}

\section{Neighbourhood}

In an attempt to facilitate

change, City Councillor Adam

Vaughan recently announced

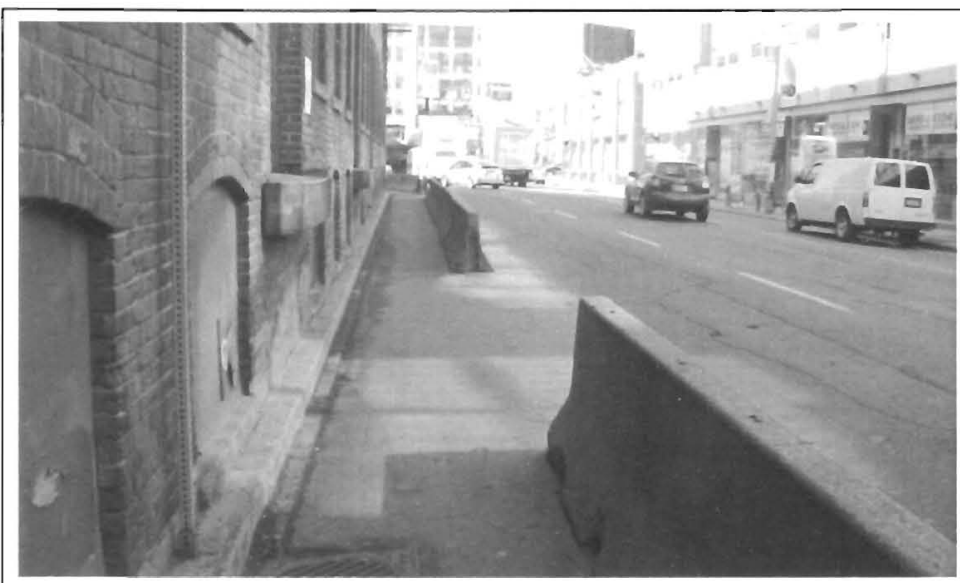

Figure 3: Makeshift sidewalk on Peter Street

his intention to convert parts of Richmond and Adelaide from one-way to two way traffic streets, in addition to creating more pedestrian space. Streets hold a great significance in mixed use neighbourhoods as they are intended to be pedestrian friendly and promote connectivity, all of which has not been present for many years since both

Richmond and Adelaide were designed to serve as express streets for drivers using the highway. Streets are part of the public realm and help effectively build character and if designed

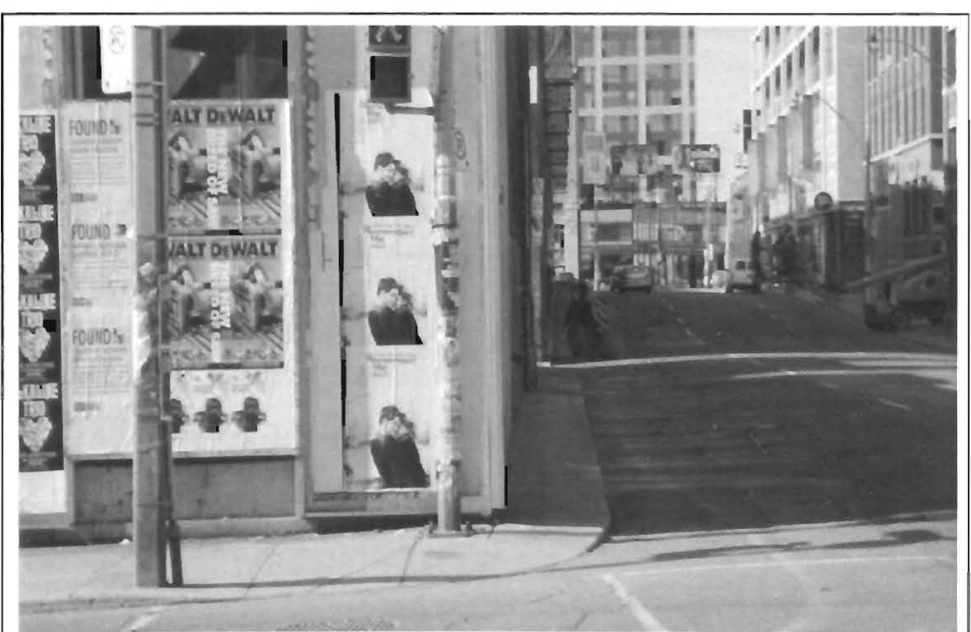

Figure 4: Limited sidewalk space on Peter Street

with people in mind, can foster sidewalk culture. Vaughan's plan is motivated by the 
desire to make the neighbourhood more liveable for the residents by creating grand boulevards to host pedestrians. Councillor Adam Vaughan's intentions of turning Richmond and Adelaide Street into two way traffic streets is based on the fact that one way streets are more conducive to speeding traffic creating an unsafe environment for pedestrians. The conversion is also based on the long term plan of creating both streets into future cycling routes in the city's bike plan.

To further expand upon this, the Toronto Entertainment District spearheaded by Executive Director, Janice Soloman initiated the creation of a multifaceted Toronto Entertainment District Master Plan under the direction of the Planning Partnership in 2008. The Toronto Entertainment District Master Plan was created with a focus on transforming a large portion of the downtown core through "the preservation of historic buildings, the promotion of local businesses and tourism, and mainly the enhancement of streetscapes, open areas and liveable pedestrian environments" (Merrit, 2009, pp.1).

As seen in Figure 5, the Master Plan makes mention of possibly creating several pedestrian friendly plazas in areas such as John Street, the space outside of the $\mathrm{CN}$ Tower, Bremner Boulevard, Union Station, Metro Square, and several small scale plazas associated with new developments (Merrit, 2009).

The Toronto Entertainment District Master Plan emphasizes improving the public realm and incorporating street furniture, installing public art while incorporating sustainable design practices (Tinglin, 2009). The Master Plan states that:

Fundamental to successful retail and mixed-use areas is a high quality public realm that is inviting to pedestrians and that entices them to walk great distances. Streets not only serve as the primary way in which people move about, they also shape how a place is experienced and often make 
the greatest impression on visitors. The Master Plan encourages the creation of great streets throughout the district to encourage pedestrian movement; to beautify the environment; and, to strengthen visual and physical connections. Furthermore, guidance is provided for a hierarchy of streetscape treatments to ensure supportive design and developments, depending on the intended pedestrian role and land use function of $a$ particular street" (2009, pg.6)

The Master Plan further includes various visual renderings which showcase what the space would look like if the public realm was enhanced within the entertainment district. The Master Plan suggests creating John Street as a central north to south street, acting as the spine of the Entertainment District as it is home to various events such as the Toronto International Film Festival and Luminato (Toronto Entertainment District Master Plan, 2009). In addition, the Master Plan reveals a new vision to rebalance the car culture and places more emphasis on creating an

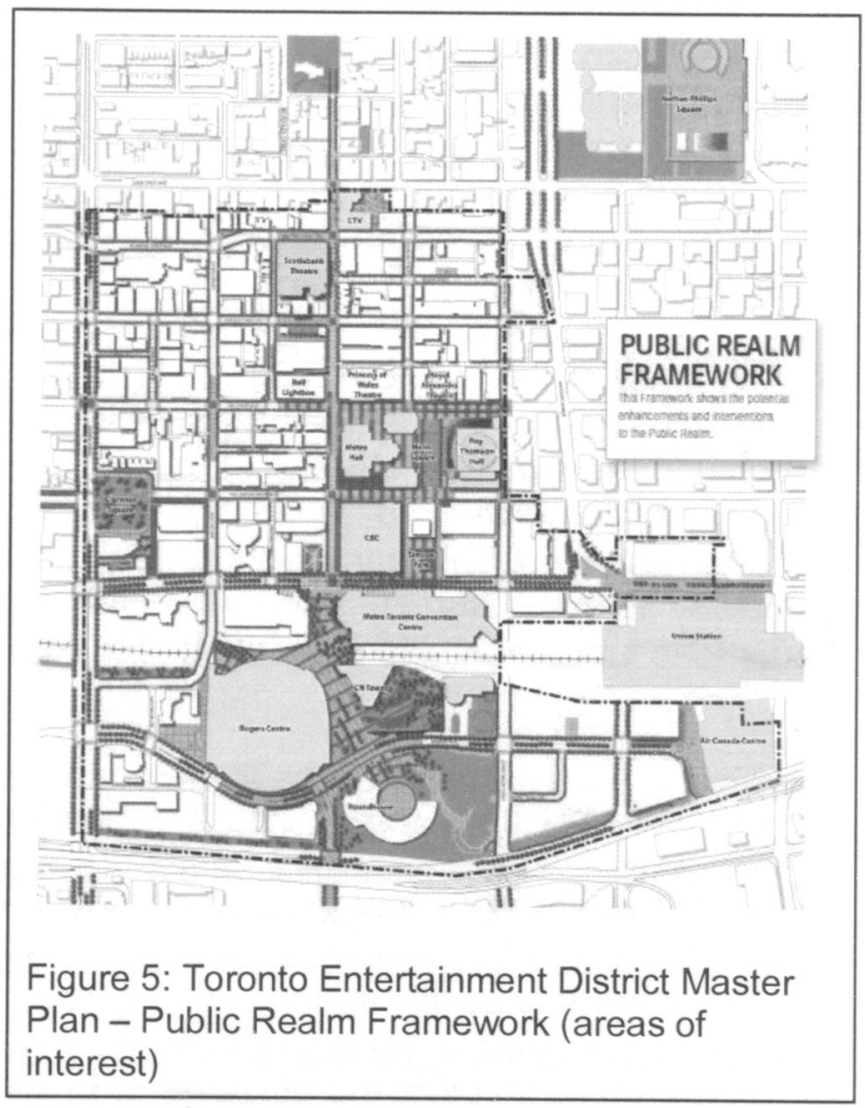
environment more conducive to pedestrians with wider sidewalks, greenery, and park space.

Creating a more conducive environment is said to help the evolution of the areas concentrated with nightclubs allowing the space to be "in its own right; back to the future of a full, balanced, and civil neighbourhood, the way it used to be decades ago. In a simple way, it is to acknowledge and develop an environment where real people 
actually live and work" (Tinglin, 2009, pg.1). The overall goal of the public realm framework discussed in the Master Plan is to provide a long term strategic vision and elements of the

Toronto Entertainment district which are in public ownership. According to the Master Plan, the primary focus of this framework is to focus on the quality of streets

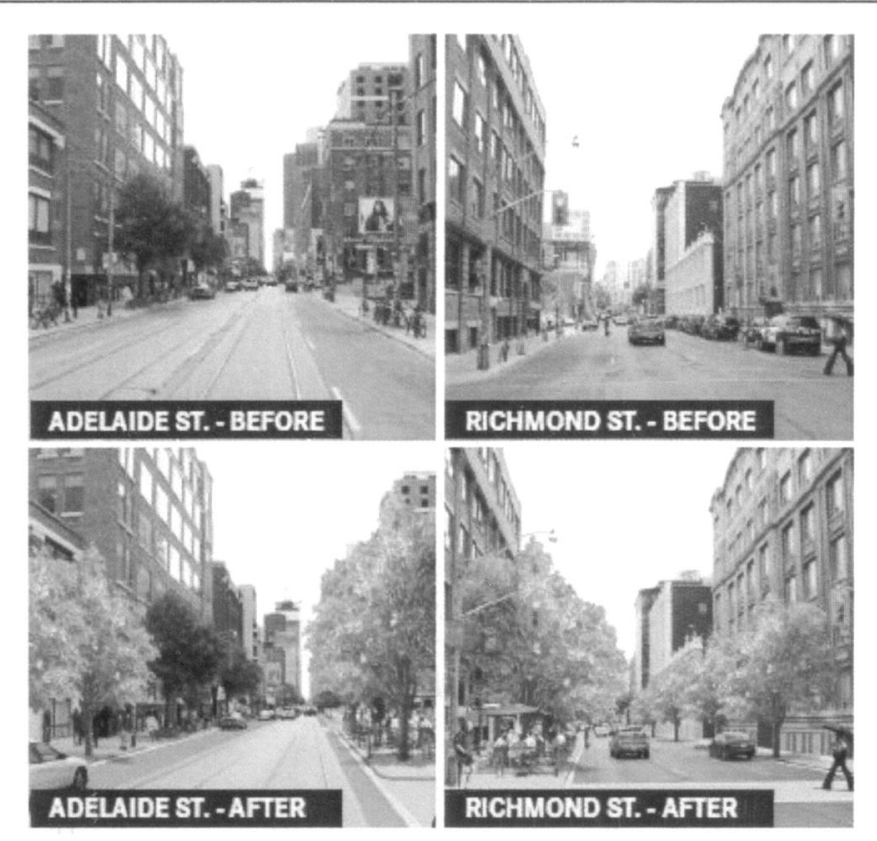

Figure 6: Richmond St. and Adelaide St. before and after renderings.

and opens spaces. This framework is said to be the most vital section of the Master plan and is fundamental in shaping the physical environment.

The Master Plan further outlines the importance of developing the neighbourhood based on mixing uses. The process will be extensive and will be a collaboration between local developers, various business owners, residents and the local City Councillor's office. There is no set timeline for the completion of the project but certain aspects of the plan, such as improving streetscaping, has been initiated (Toronto Entertainment District Master Plan, 2009). While this project seems grandeur and focused on improving the area, funding is not guaranteed and no final dollar figure has been set as to how much the entire project would cost. All that is known today is that the project will be ongoing, and that funding will likely come from a variety of sources over time (Merrit, 2009). 


\section{Chapter 5: Conclusion}

\section{$\underline{5.1 \text { Discussion }}$}

The public realm is defined as space communally shared amongst the public. The concept is "intimately linked to the ideas of universal access, the common ground, and shared amenities" (Gregory, 2000, pg.ii). Cities include a composition of both public and private space, including various land uses and individuals. The essence of a city can be examined through the interactions of its various users. Cities are often never static and change constantly over time. This is evident in the King-Spadina neighbourhood. Evolving from its industrious past, the space has transformed into a multifaceted community, home to many. A neighbourhood which once saw a complete decline and sudden abandonment today consists of some of the nation's most valuable properties (Clubland, 2008).

The drastic change in the planning framework was originally implemented to allow for the reinvestment in the space after the decline. Through this research, it has been determined that from a planning perspective, the change allowed for successful reinvestment in the space. Not only has the area attracted a significant amount of business and economic growth, but several new residential developments. The area has all the means for a highly desirable mixed use neighbourhood.

As previously stated, there has been a constant battle and tension between the residents and business owners in the King-Spadina area in regards to whom the space belongs to. Each land user appears to feel a sense of entitlement to the space and is leaving very little room for compromise. Residents have claimed that the nightclubs do 
not belong in the entertainment district and nightclub operators and promoters say that no one purchases a $\$ 400,000$ dollar condominium in the neighbourhood without knowing what they are getting into (Clubland, 2008).

In addition to the conflicts between the various land users, this research has determined that issues are prevalent in the public realm of the neighbourhood. The King-Spadina neighbourhood previously served as an industrial area, due to this a very small amount of concentration was paid to the public realm. Over time, while the space has evolved, it has become apparent that recognizing that improvements to the public realm are vital in order to make this previously industrial district more attractive and welcoming for pedestrians.

As the neighbourhood continues to evolve, improvements in the public realm play a vital role in further enhancing the area. As stated in the literature by Lyndon (1995), much attention and constant care needs to be paid to these shared spaces. The public realm acts as shared space between its various users and plays a contemporary role in urban life. By improving the public realm it is possible to create enough space to cater to the various users. In the documentary Clubland (2008), it was seen that often intoxicated club goers would stumble onto private residential properties yelling, vomiting and acting indecently. It was found that one of the common concerns stated by residents, City Councillor Adam Vaughan, and Toronto Police was the fact that the area is not safe due to the mass volume of people in the area. As a former industrial area, much attention was not given to the public spaces or pedestrian amenities in the area and therefore the public realm is not equipped to handle such large numbers of people. 
The issue at hand is that there are clearly various groups of individuals (residents versus nightclub operators, residents versus club goers) who have different views as to what is right and what is wrong. With such a high concentration of nightclubs in given neighbourhood, in addition to a growing population in the area and weekly nightclub goers surpassing 60,000 , the issue and conclusion is that the public realm is not equipped to handle this sheer number of people. While improving the public realm may not be a resolution to all of the issues between both users (such as noise and rowdy behaviour), it can aid in providing solutions to the overall neighbourhood. Enhancing and improving the public realm would not be the sole solution in solving the problems apparent in the neighbourhood, but rather it would serve as a stepping stone in improvements. The conflicts at hand are complex and multifaceted and there is no one solution to solving the problem.

While some may claim that the nightclubs are being overly enforced due to excessive residential complaints, when asked ideally what the residents would like to see in the neighbourhood Councillor Adam Vaughan responded that "it is not necessarily about shutting the nightclubs down, the majority of the concerns are based around safety... residents are not opposed to nightclubs in the area they are opposed to nightclubs which do not operate properly...the problem is these big box Walmart styled nightclubs, these types are no longer desirable and often attract a certain crowd" (personal communication, 2010).

According to Janice Solomon, "it is the large nightclubs which people often complain about, you do not hear half as many complaints coming from those who reside near the smaller more intimate lounge type nightclubs located on King Street... the 
crowd is much more mature on King Street, it is highly unlikely that you will find massive crowds of younger teenagers running across King Street shoeless acting in a indecent manner, a scene often prevalent on Richmond Street (personal communication, 2009).

She further stated that the discussion around "who owns the neighbourhood needs to stop as it is irrelevant, it is now a mixed use neighbourhood and it does not matter who was there first, the point is that they are there now and need to find a way to co-exist" (personal communication, 2009). With this being said, some may still claim that the local residents and Councillor are intent on shutting the nightclubs down, but it has become apparent through this research and my interviews that this is not what is intended. The intention is to create a mixed use neighbourhood which has a well balanced mix of various uses. The goal is to create an environment which is conducive to business owners, patrons and residents.

Enhancing the public realm will foster a better mixed use neighbourhood as it will be better equipped to handle the various land users, such as residents, business owners and patrons. The public realm needs constant care and is a vital part of cities as it is the space in which people move through. improvements can be made through maintaining, repairing and enhancing public spaces to better allow for civil interactions (Lyndon, 1995 \& Loflyn, 1989). Mixed use neighbourhoods and the public realm both encourage social interaction and integration.

In the case of the King-Spadina neighbourhood, as seen through this research and my observational study, the area lacks a public realm, one which is equipped to handle the population that resides in it and those who use its services (residents, club 
goers, tourists, \& patrons). Recognizing improvements in the area would possibly make it more desirable and enjoyable for all its users. While the City of Toronto has invested in improving the public realm in sections of the King-Spadina neighbourhood, it is vital that additional improvements be made in areas which have high concentrations nightclub venues. By doing so, it is possible that certain issues of safety might not be as prevalent as they are today. It is important to create spaces which are not only more equipped to handle more individuals, but also have safer public spaces, such as sidewalks. Academics such as Loukaitou-Sideris (2009) and Jacobs (1961) would argue that public places, such as sidewalks, are vital organs of the city; they are places which are active sites for socialization and pleasure which help keep neighbourhoods safe and under control.

In moving forward, it is imperative for the City of Toronto to work in conjunction with the Toronto Entertainment District Business Improvement Area to enhance the public realm within the King-Spadina neighbourhood. The Master Plan not only outlines improvements in the area in terms of business, but also focuses heavily on moving forward on the basis that the area is a mixed use neighbourhood and that the needs of its various users need to be incorporated rather than just businesses. The Master Plan appears to be a great long term plan in the betterment of the neighbourhood and is focusing on creating a more pedestrian friendly community for its various users. The Master Plan asserts that while there are several infrastructural changes that need to be made over a long period of time, there are also smaller scale projects that can take place such as streetscaping, beautification, increased lighting and other small scale public realm improvements. 
While we move into a future of planning where sustainable communities and practices are vital frameworks to follow by, it is important that more research be conducted into modern forms of mixed use and the issues that arise in these neighbourhoods. If these types of communities are going to be promoted by local governments and public figures, the general public needs to be involved in an active participation process to address any concerns they may have. Planners must play an active role in observing incompatible land uses and attempt to find additional ways to manage future conflicts whether it is through zoning amendments, urban design, civic engagement or other affective planning tools. Through this research, it has become apparent that there is no single solution in resolving the issues in the King-Spadina neighbourhood. Where there are different land uses, there are often various options, views and concerns. Therefore, while enhancing the public realm may not be the only solution for solving the conflicts in the Entertainment District, it can assist in creating a better environment when combined with progressive and sustainable planning approaches. 


\section{REFERENCES}

Atlanta Regional Commission, Initials. (nd). Developments of excellence. Retrieved from http://www.atlantaregional.com/land-use/developments-of-excellence

Bacon, E.N., (1974) The design of cities, Thames \& Hudson

Bohl, C. (2000). New urbanism and the city: potential applications and implications for distressed inner-city neighbourhoods. Retrieved from http://www.mi.vt.edu/Research/PDFs/poticha.pdf

Canadian Mortgage and Housing Corporation, Initials. (2004). The Kings regeneration initiative. Retrieved from http://www.cmhc-

schl.gc.ca/en/inpr/su/sucopl/upload/The-Kings-Regeneration-InitiativeToronto-Ont.pdf

California Downtown Association (nd) Design guidelines, Retrieved from: http://www.californiadowntown.com/

Calthorpe, P. \& Fulton, W., (2001). The regional city: planning for the end of sprawl, Washington, DC: Island Press

Carmona, M, Heath, T, Oc, T, \& Tiesdell, S. (2003). Public spaces urban spaces. Burlington: Architectural Press.

Center for the Living Cities, Initials. (2008). The Legacy of jane jacobs: understanding authentic urbanism.4, Retrieved from:http://www.centerforthelivingcity.org/wpcontent/uploads/authentic_urbanism.pdf

Cervero, R. (1988) Land use mixing and suburban mobility. Transportation Quarterly, $42: 3$

Clark-Madison, M (1999) Naked city, Retrieved from: http://www.austinchronicle.com/gyrobase/lssue/story?oid=oid:

Clement, B.J., Durfee, H., Barrett, A.C., (2007) Abstract reasoning for planning and coordination. 28:453

Charrette Centre. (2004). Designing centers boost inner city revitalization. Retrieved from Center for the Living Cities, Initials. (2008). The Legacy of jane jacobs: understanding authentic urbanism. 4, Retrieved from http://www.centerforthelivingcity.org/wpcontent/uploads/authentic_urbanism.pdf

City Comforts, (2004). Boiling a zoning code down to basics. Retrieved from http://citycomfortsblog.typepad.com/cities/2004/06/eye_we_need_a_n.html 
City of Rockville (nd) Design guidelines, Retrieved from:

http://www.rockvillemd.gov/towncenter/design-guides.htm

City of Toronto Urban Development Services, Initials. (2002). Regeneration in the kings: directions and emerging trend. Retrieved from http://www.toronto.ca/planning/pdf/kingsmonit.pdf

City of Toronto (2006) Census data, Retrieved from: http://www.toronto.ca/planning/kings_execsum.htm

City of Toronto (2009) Secondary plan review, Retrieved from: http://www.toronto.ca/planning/pdf/king_spadina_final_pt1.pdf

City of West Salem,. (2008). Draft neighbourhood center mixed-use zone. Retrieved from http://www.cityofsalem.net/NCMU

Coppock, J.T. (1978) Land use. New York: Pergamon Press.

Coupland, A.(Eds). (1997). Reclaiming the city: mixed use neighbourhoods. London: Aden Press, Osney Mead, Oxford.

Dear, M.J., (2000) The post modern urban condition. Oxford: Blackwell Publishers Ink

Duany, A., (2000) Gentrification and the paradox of affordable housing, Retrieved from: http://www.riverwestcurrents.org/2002/July/000036.html

Frank, L.D, \& Pivo, G. (nd). Impacts of mixed use and density on utilization of three modes of travel: single-occupant vehicle, transit, and walking. Retrieved from http://www.u.arizona.edu/ gpivo/Frank\%20and\%20Pivo.pdf

Freedman, B., (1999) Managing land use and land cover change: The New Jersey Pinelands. Annals of the Association of American Geographer, 89:2

Gallent, N., Sik Kim, K., (1998) The changing housing role of mixed use development in Seoul. Liverpool University Press

Gardiner, K. (nd) Best marketing practices for large-scale mixed use developments, Retrieved from: http://www.kevingardiner.com/MUBestPractices_KGA.pdf

Geringas, E., (2008) Clubland, Retrieved from: http://news.globaltv.com/Clubland/2055010/story.html

Gordon, P., (1998) A critique of new urbanism. Retrieved from: http://www.rcf.usc.edu/pgordon/urbanism.html

Grant, J., (2002) Mixed use in theory and practise: canadian experience with implementing a planning principle.Journal of the American Planning Association: 68:1. In B, Stiftel, V, Watson. (Eds) New York: NY Routeledge

Grant, J., (2005) Rethinking the public interest as a planning concept. Retrieved from: http://www.cip-icu.ca/_CMS/Files/PC45215.pdf 
Grant, J., (2004) Encouraging mixed use in practise. Retrieved from:

http://74.125.155.132/scholar?q=cache:PFF_d4ZZOGoJ:scholar.google.com/

$+\mathrm{Jill}+$ Grant+mixed+use+2004\&hl=en\&as_sdt $=2000$

Gray, J., (2007) Adam Vaughan gets tough on nightclub, Retrieved from:

http://www.blogto.com/city/2007/05/adam_vaughan_gets_tough_on_nightclub sl

Gregory, K., (2000) Public realm planning and design: creating more livable communities. Retrieved from:

http://circle.ubc.ca/handle/2429/10630?show=full

Hendler, S., (1989) The Canadian healthy communities project: relevant or redundant? Plan Canada, 29:4

Houston Galveston Area Council (nd) Urban design best practices toolkit, Retrieved from: http://ntis04.hgac.cog.tx.us Websites

Howard, E., (1965) Garden cities of tomorrow. Great Britain; MIT Press

Hume, C., (2010) Toronto's little details a big deal for residents. The Toronto Star. Retrieved from: http://www.thestar.com/yourcitymycity/article/776192--humetoronto-s-little-details-a-big-deal-for-residents

Jacobs, K., (1961) The death and life of great American cities, New York: Random House

Kempsey Shire Council (nd) Conflicting land use: buffers. Retrieved from:

http://www.kempsey.nsw.gov.au/pdfsDCPs/DCP12conflanduses.pdf

King-Spadina Residents Association. (2008) Reports of disturbance, Retrieved from: http://www.king-spadina.com/

Klien, L., (2008) The changing landscape for mixed-use developments: risks, threats and opportunities, Retrieved from:

http://www.realestateforums.com/LandConference/ppt/Session\%20A1\%20$\% 20$ Les $\% 20$ Klein.pdf

Land Buffer Task Force (2007) General definition and types of land buffers. Retrieved from:

http://www.fresnocog.org/files/LandBufferTaskForce/LBTF_Mtg01E_012507.p df

Lofland, L., (1989) The morality of urban public life: the emergence and continuation of a debate. Places, 6(1), 18. Retrieved from:

http://escholarship.org/uc/item/3k82388j

Lofland, L (1993) The public realm: exploring the city's quintessential social territory. Aldine de Gruyter. 
Loukaitou-Sideris (2009). Sidewalks: conflict \& negotiation over public Space: MIT Press

Lynch, K., (1984) Good city form, Cambridge: MIT Press

Lyndon, D., (1994) Caring about places...designing the public realm. Places Journal, 9:2 Retrieved from: http://escholarship.org/uc/item/6s1083dh

Lyndon, D., (1995) Caring about places... prospects for an improved public realm. Places Journal, 10:1

Lynes, J., Murray, D., (2007) Mixed use neighbourhoods, Retrieved from: http://www.alternativesjournal.ca/mixed-use-neighbourhoods

Madera, C.P., (2008) People like cars, and there's not much you can do about it, Retrieved from: http://www.planetizen.com/node/31104

Merrit, S. (2009). Entertainment district's master plan. Spacing Magazine, Retrieved from http://spacing.ca/wire/2009/06/16/entertainment-districts-master-plan

McGill University (2009) Urban design and housing, Retrieved from: http://www.mcgill.ca/urbandesign

McLaughlin, R., (2001) Planning the public realm. Retrieved from: http://www.charrettecenter.com/articles/lexicon5.pdf

McMahon, E., (1999) Making a visible difference, Planning Commissioners Journal 99:36

Miller.D., (2003) How a justifying government purpose can overcome the disparate impact problem: Saint Louis University Law Journal, Retrieved from: https://itigation-essentials.lexisnexis.com/

Moore, A., Henderson, R. (1998) Plan obsclescence, Reason Magazine, Retrieved from:http://reason.com/archives/1998/06/01/plan-obsolesence

Mudhar, R., (2007) Condos and clubs clash. Retrieved from: http://www.thestar.com/entertainment/article/218303

Mumford, Lewis (1961) The city in history, San Diego, Harcourt Inc

Muswellbrook Shire Council (nd) Development control plan, Retrieved from: http://www.muswellbrook.nsw.gov.au/Council-services/Planningdevelopment/Development-control-plan-pdfs/Section $\% 208 \% 20-$ \%20Rural\%20Development.pdf

Neuman, W. Lawrence. (2006). Social research methods: qualitative and quantitative approaches. 6th ed. Pearson.

na, . (2010). Define incompatible . Merriam-Websters dictionary. Retrieved (2010, April 3) from http://www.merriam-webster.com/netdict/incompatible 
Pendall, R., (1999) Do land use controls cause sprawl? Environmental and Planning Journal 26:4

Powell, E.B., (2004) Mixed feelings about mixed use. Retrieved from: http://www.djc.com/news/re/11161876.html

Project for Public Spaces (nd) Jance Jacobs- biography, Retrieved from: http://www.pps.org/info/placemakingtools/placemakers/jjacobs

Raising the Bar Forum (2008) Alcohol and violence. Retrieved from: http://www.apolnet.ca/news/ITW/ITW-Apr09.html

Robert, D., Arthur, S., (1958) Oil and gas development and production in California as restricted by conversation, nuisance and zoning regulations. UCLA: REV

Shmandt, M. (1999) The importance of history and content in the postmodern urban landscape. Landscape Journal, 18(2)

Siddiqi, M., (2009) The consequence of curbing clubland. Retrieved from: http://network.nationalpost.com/np/blogs/toronto/archive/2009/10/10/theconsequences-of-curbing-clubland.aspx

Soloman, J (2009) Interview with Janice Soloman on December $18^{\text {th }}, 2010$

Stiftel, B., Watson, V. (2005) Introduction: building global integration in planning. Journal of Planning Education and Research. 28:2

The Hemson Toronto Land Use Report. (1991) Toronto land use report. Retrieved from: http://www.nrupublishing.com/files/HEMSON/910531TPD.pdf.

The Planning Partnership (2006) King-Spadina secondary review, Retrieved from: http://www.toronto.ca/planning/pdf/king_spadina_final_pt1.pdf

The Vancouver Sun (2008) New urbanism means making the automobile less necessary, Retrieved from: http://www.canada.com/vancou versun/columnists/story.html/6b5ba

Toronto Entertainment District BIA (2009) Master Plan. Retrieved from: http://www.torontoed.com/masterplane.html

Tinglin, H.C., (2009) Vaughan slows the entertainment district beat, The Torontoist, Retrieved from: http://torontoist.com/2009/06/vaughan_slows_the_beat.php

Tombari, E., (2005) Smart growth, smart series: mixed use developments; National Association of Home Builders. Retrieved from: http://www.nahm.org/fileupload_details.aspx

Urban Design Compendium (2007) A thriving public realm, Retrieved from: http://www.urbandesigncompendium.co.uk/thrivingpublicrealm 
Vancouver Public Space (2009) Public realm report card, Retrieved from: http://vancouverpublicspace.ca/index.php?page=urbandesign

Vaughan, A (2010). Interview with Adam Vaughan on January $14^{\text {th }}, 2010$

Velibeyoglu, K (1999) Urban design in the postmodern context. Retrieved from: http:angelfire.com/ar/corei/ud.html

Wai, I.K., Chi Chung, L., Wong, F.K., (2003) Exploring geography, Hong Kong: Oxford University Press

Witty, D., (2002), Healthy communities: what have we learned? Plan Canada, 42:4

Zelinka, A., Smart, A, K., Kunz, K., (2005) Making the most of mixed-use, Retrieved from: http://uww.allbusiness.com/environment-naturalresources/landusedevelopment 


\section{Image Sources:}

Figure 1: Image Source: The City of Toronto

Figure 2: Image Source: Sharan Kaur

Figure 3: Image Source: Sharan Kaur

Figure 4: Image Source: Sharan Kaur

Figure 5: Image Source: Toronto Entertainment District BIA

Figure 6: Image Source: Toronto Entertainment District BIA 